\title{
O Problema da Educação Nacional
}

\section{Margarida TeIXeIra Herig}

Com a publicação do presente artigo, inicia a "Revista do Serviço Público", por sugestão do Prof. Elpídio Pimentel, Diretor dos Cursos de Administração do Dasp, a divulgação de trabalhos da autcria dos alunos que mais se destacaram na conclusão de cursos específicos. Nêste, a aluna Margarida Teixeira Herig, ao terminar um curso especial para redatores, levado a efeito no último ano letivo, focaliza, com inteligência e elegância de estilo, problema fundamental, qual o da educação nacional, revelando-se, assim, um valor que merece ser incentivado, tal como outros que têm passado e, certamente, ainda passarão por aquêles cursos. (N.R.).

\section{O PROBLEMA DA EDUCAÇÃO NACIONAL}

E DUCAÇÃo é, no entendimento completo do têrmo, desenvolvimento harmônico do homem, capaz de torná-lo física, intelectual, espiritual e moralmente apto a integrar-se na vida como fôrça positiva do progresso. Educação é, pois, cultura e treinamento, conhecimento da vida, compreensão da natureza humana, conceituação verdadeira de si mesmo.

E' quando as criaturas humanas alcançam a origem da vida e começa a existir um novo ser, que deve ser iniciado o difícil e grandioso trabalho da educação, que se há de fazer sentir nos hábitos salutares đa mãe, no seu pensamento justo, na alimentação sadia, no seu ideal criador, enfim. Nascida a criança, deve-se prosseguir, sem solução de continuidade, essa tarefa divina da educaçäo. E' preciso, então, metodizar a vida da criancinha, mesmo quando ela começa a se adaptar ao mundo.

Aparece, aí, a primeira grande agência de educação: o lar. A criança. como uma chapa fotográfica, vai registrando as impressões recebidas, inconsciente, mas indelevelmente. O comportamento dos pais, o clima afetivo do lar, a alimentação e o método, mais o que foi transmitido dos pais pelo milagre da vida, vão formando a personalidade da criança.

Depo1s, a necessidade de associar-se a outra criança aparece, e a criança sente que brincar só não é o mais interessante; e chega o dia de ir para o jardim da intâncià, a escola desejada, a segunda grande agência de educação.

Ali, a criança vai levar o patrimônio sagrado que traz consigo e vai modificá-lo e engrandecê-lo no intercâmbio que realizará com os professôres 
e companheiros. As associações de classe e as visitas que recebe e que realiza lhe vão dando a idéia associativa. Os anos passam, e o ensino ministrado, as liçōes recebidas, o exemplo proporcionado, as experiências realizadas vao ampliar o seu mundo e proporcionar a revelação dos mistérios de sua personalidade.

A idade da imitação sucede a do discernimento, das comparações e deduções; o raciocínio se aclara, a inteligência se explana e se aprofunda, e, se não foi traída a obra magnífica da educação, o adulto surge como força positiva, que, integrando-se na comunhão universal do trabalho, vai atuar como fator do próprio engrandecimento. A obra da educação vai, então, encontrar a sua terceira grande agência - o trabalho.

Realizando um programa, traçando-o ou planejando-o, o homem trabalha para atender ao mandamento divino: "Ganharás o pão com o suor do teu rosto", ou porque sente a necessidade de trabalhar para crescer intelectualmente, para aumentar a área de sua sensibilidade, para se sentir partícipe da Humanidade.

Uma criatura sem educação é qual terra virgem que mão amiga inda nào desbravou e que jaz inerte à mercê dos cardos e espinhos que ao seu lacio vicejam.

Mas, para que a educação atinja a sua grandiosa tarefa de humanizar o homem, é preciso começar pelo pensamento. Que a criança e o adolescente pensem por si mesmos e venham a agir dentro da norma ditada por êsse pensamento que a educação ajustou. Para tanto, a escola precisa vivificar-se; ssto é, ser trazida para a vida ou que se leve a vida para dentro dela.

O ensino secundário deve ser ministrado sôbre bases humanistas; de tormação đo nomem integral, e não como mera comunicação de conhecimentos. O espirito deve ser educado na simplicidade da lógica para adquirir os hábitos da exatidão e flexibilidade pela prática da análise e da síntese. 0 estudo da Língua deve ser a alavanca que erguerá o homem à grandiosa missão que lhe compete. A Matemática deve ser estudada na apreensão da verdade. A História deve ser vista, não como uma sequiência de fatos, mas como uma busca dos motivos que dirigem as ações humanas, baseando-se a tormação ñistórica na sinceridade e na imparcialidade. A ciência, enfim, há que ser o guia que conduzirá o homem ao seu superior destino. Se se conseguir êsse objjetivo, isto é, se a cultura fôr posta à serviço do aparfeiçoamento da humanidade, se o homem aprender a medir a grandeza do universo e a sentır as harmonias da vida pela afinação de seus sentidos, então, o médico não será sòmente um formulador de receitas, o professor um transmissor de conhecimentos, o juiz um dirimidor de conflitos, o advogado um taxador da lei, mas todos, em conjunto, trabalhando com alma, serão, os edificadores de um munđa solidário e cristão. Tempora venient... E' preciso crer, trabalhar e esperar.

Crendo, certificando-nos da nossa grandeza a par com o infinito de nossa miséria.

Trabalhando, havemos de buscar no amor a fôrça para a luta e na cultura o discernimento para nortear-nos o caminho. 

e capaz.

Esperando, acalentemos a certeza de que somos um povo inteligente

Bem sabemos todos que o nosso problema é o da honestidade, da perseverança, da disposição para o trabalho, da saúde, da educação, enfim.

Fale-se em honestidade desde a escola maternal até o último ano das universidades.

Ajustem-se os salários de tôdas as classes para atenuar a fôrça das tentaçōes que a miséria fomenta.

Cuide-se da saúde de nosso povo, para que o pensamento se purifique por influencia do sangue purificado. E realizando-se nos colégios, nas repartiçöes, em todos os locais de trabalho, conferências, estudos da vida de grandes propulsores do progresso, ressaltando-lhes o valor moral e trazendo à nossa gente a certeza de que somos um povo capaz, idealista e bom, é que, senhores de nossa própria terra e de nosso próprio destino, podemos realizar a redençào nacional, levando o nosso caro Brasil para o lugar que the cabe no concêrto das nações.

"A tarefa de dirigir pessoas, no sentido da realização de qualquer objetivo, sugere o exame de aspectos de natureza diversa, por isso mesmo que os problemas respectivos apresentam um caráter ora psicológico (relações humanas entre chefes e subordinados, dos chefes entre si, etc.) ora técnico-administrativo (definição de atribuições, distribuição racional do tempo, métodos de direção, etc.) ora ainda moral (responsabilidades da chefia, formação do moral do grupo, etc.). Daí o inevitável ecletismo notado na distribuição da matéria, que abrange desdé a definição do tipo de chefia autocrática, o exame dos processos de influenciação dos subordinados ou dos fatôres condicionantes do moral do grupo até a consideração dos instrumentos de chefia de uso mais corrente como a expedição de ordens, etc. Isso não significa, portanto um tratamento heterogêneo, senão que reflete apenas aquela diversidade de aspectos, exigindo, uns, exames mais completos e, outros, considerações digamos, mais "terra a terra".", mas).

(WAgner Estelita Campos - "Chefia", sua técnica e seus proble- 